DOI https://doi.org/10.18551/rjoas.2021-01.08

\title{
ANDROID BASED MEDIA INNOVATION FUNCTION MODEL ON THE FARMING OF PADDY TOWARD IMPLEMENTATION OF FIVE FARMING SYSTEM IN THE DISTRICT OF TANJUNG JABUNG BARAT, INDONESIA
}

\author{
Pera Nurfathiyah*, Saidin Nainggolan \\ Department of Agribusiness, Faculty of Agriculture, University of Jambi, Indonesia \\ ${ }^{\star}$ E-mail: pera nur@unia.ac.id
}

\begin{abstract}
This study aims to (1) analyze the factors that affect the innovation function of android-based extension media in lowland rice farming on the application of five farming, (2) obtain a model of the innovation function of android-based extension media on rice farming to the application office farming. The method of this research is experimental research with posttest design and posttest control group design and data analysis with structural equation modeling (SEM) using a sample of 60 farmers. The result is that the loading value of the constructs of the sustainability of farming (economic, environmental and social aspects) is $0.984,0.961$ and 0.960 , which are higher than the cross loading indicators of other latent constructs.
\end{abstract}

\section{KEY WORDS}

Android application, extension media, rice field, five farming principal.

Human civilization and communication move according to human needs for information from using communication symbols to communication using technology. At any time along with the penetration of mobile, hundreds of millions of global population connected to each other generate, and publish information all over the world using android based communication media. The process of rapidly developing information also occurs in agriculture. Mobile and social media applications in agricultural extension continue to develop. At the same time, there is a global realization for a "New Extension" with new capacities and changing roles to address challenges in agricultural development and also to ensure food security for a growing global population. A number of innovative mobile phone and social media applications have emerged and are experimenting to fulfill the new and expanded role of extension. The research of Aravanan R. and Suchiradipta B. (2013) shows that the use of Android-based mobile phones and social media can facilitate agricultural extension to shift from "information facilitation to enabling innovation and empowerment" among stakeholders in agricultural innovation systems.

Extension material can not only be delivered verbally, face to face and demonstrations by agricultural extension workers but can use other media that can explain the material in more detail, attract attention, give a deep impression so that farmers do not easily forget it and can be repeated if the material presented is lacking understood by farmers. Androidbased extension media is one of the media that can be designed so that it can convey information in an interesting and inspiring way to do what is conveyed because there are elements of motion pictures, text, sound, color. This is confirmed by the results of research by Lu te you and Chang Y.H (2016) showing that the use of media can improve the distribution of information technology and can help farmers in information literacy so that they can increase the production of agricultural products. Extension materials were delivered by Agriculture Extension Workers (AEW) to farmers in Sri Agung and Rawa Medang villages through face-to-face communication and $A E W$ rarely used extension media as a tool to clarify the material presented. Extension activities that rarely use extension media can cause farmers to often forget the material presented by AEW so that if farmers want to ask AEW they sometimes have to wait a few more days to meet AEW who only visit 3-4 times a month. The limited intensity of AEW visits has resulted in the embrace of the media which can replace the role of $A E W$ if the information conveyed by $A E W$ is not understood by farmers. In addition, the role of the media can also replace AEW if $A E W$ is unable to attend. Extension 
media that can explain in detail the extension material is an Android-based extension media. This media is included in multimedia because it can combine still images, animation, audio in one application media package so that it can increase farmers' understanding and skills about the message material conveyed by AEW because the appearance of this media is attractive, interactive and innovative. There is no Android-based extension media which explains the five lowland rice farming in Sri Agung and Rawa Medang villages, so this research aims to find innovations in the form of android-based extension media technology and to analyze the role models of android-based extension media.

Agricultural extension is the empowerment of farmers and their families as well as agribusiness communities through non-formal education activities in the agricultural sector so that they are able to help themselves both in the economic, social and political fields so that increasing their income and welfare can be achieved by the Ministry of Agriculture (2002). Agricultural extension agents are here to assist farmers in developing or restructuring their behavior to become modern, resilient and efficient farmers (Madjid, 2006). This is supported by the results of research by Zakaria $S$ and Nagata, $H$ (2010) showing that the role of extension in agriculture plays a very important role in increasing cooperation between farmers, extension workers and the government (stakeholders) in solving farmer problems. The extension system according to RI Law no. 16, concerning SP3K, 2006 is an activity to develop the abilities, knowledge, skills and attitudes of the main actors and business actors so that they are willing and able to help and organize themselves in accessing market information, technology, capital and other resources, as an effort to increase productivity, business efficiency, income, and welfare, as well as increasing awareness in the preservation of environmental functions.

Innovation is creating something new, generating new ideas, new tools, improving existing ones doing things in a new way, seeing things from a different perspective, following the market and making changes. Innovations can be in the form of tools, ideas, methods etc. that can help human work to be more effective and efficient, one of the android-based extension media for farmers (Nadjib, A. 2016). Android-based extension media has an application function as a medium for educational functions, social functions (environmental, economic functions, arts and cultural functions. Widodo, S (2014), namely: (1) Educative Media, ICT media are used as educational media that provide influence or value good for farmers and tools (2) Social media, media that can connect with other people, recognition and understanding of an object in the form of information about people, customs, how to get along and everything related to social problems in society, (3) Economic Media is a function of ICT Media to assist in increasing products and market opportunities, (4) Media Art and culture is a medium that produces innovation. Extension media are tools that are produced in such a way as to assist in conveying messages or extension materials to farmers so that farmers can absorb messages clearly. Extension media is an object packaged in such a way as to facilitate delivery of material to targets, so that targets can absorb messages easily and clearly (Sari MD and Surayya, M. 2018). Extension media based on their functions are: (1) print media, namely media that prioritizes visual messages from images and words in color arrangements using a printing process in producing them, for example booklet, folder, leaflet, poster media, (2) electronic media, namely media that uses image effects motion, still images and audio in the process of delivery, for example television, radio, video film, cassettes, CDs, VCDs and Android-based mobile phones and (3) Outdoor Media, namely this media is a medium used in conveying messages outside the classroom. Android application-based extension media is included in electronic media. Android used is an operating system for cell phones based on Linux, Android provides an open platform for developers to create their own applications so that they can be used by a variety of mobile devices. According to Safaat H. (2011: 1) Android is an operating system for Linux-based mobile which includes an operating system, middleware and applications. Android provides an open platform for developers to create their applications. According to N. S. H (2012) that Android Mobile application programming is a new generation of mobile platforms, a platform that provides developers to develop as expected. 


\section{METHODS OF RESEARCH}

This research was conducted in Batang Asam District, West Tanjung Jabung Regency. The selection and location determination was done purposively with the consideration that Batang Asam Subdistrict is the highest rice producing area in West Tanjung Jabung Regency which has the potential to increase its production better than before as well as the advancement of agricultural technology used by farmers. This research was conducted from 01 April - 01 October 2020. This research was conducted in 2 villages, namely Sri Agung and Rawa Medang villages. The data collected in this study include primary data and secondary data. Primary data is obtained from interviews with farmers based on a list of questions / questionnaires, while secondary data is obtained from literature studies from books, articles in scientific journals, scientific papers, reports that have been recorded and published. The object of this research is farmers who use android as a medium of extension in seeking information about the application of five rice farming. The population of this study was 779 lowland rice farmers in Sri agung and Rawa Medang villages, Batang Asam district, Tanjung Jabung Barat regency, of which 779 people were selected purposively with the criteria of farmers using android as a medium of extension in seeking information about five farming. , farmers who cultivate lowland rice plants and apply five farming practices, minimum education level of junior high school, not color blind, maximum age 55 years so that 60 farmers are obtained. Furthermore, the sample was randomly divided into 4 treatment groups where each group consisted of 15 people. During the two weeks before conducting the research, data on response characteristics were first collected which included: age, education, experience of lowland rice farming, exposure to the media, interactions with PPLs, interactions with fellow farmers and groups and institutions both inside and outside.

This research design uses two approaches, namely:

1) The pure experimental method (true experiment) and the method using the pretest posttest control group design. The independent variable is the design of android-based extension media about the five rice fields. The dependent variable is the increase in knowledge after using extension media. The characteristics of the pre-test, post-test and control group design research types are to reveal a causal relationship involving 2 treatment groups and 2 control groups, namely the untreated group. The treatment group was observed prior to intervention, and then observed again after the intervention (Nursalam, 2011). This design does not use a comparison group (control), but a first observation (pretest) is carried out which allows testing the changes that occur after the experiment (Notoadmodjo, 2010). The form of this design is as follows:

Table 1 - Research Design

\begin{tabular}{|c|c|c|c|}
\hline Subject & Pre-test & Treatment & Post-test \\
\hline $\mathrm{K} 1-\mathrm{K} 2$ & $\mathrm{O} 1$ & $\mathrm{X}$ & O2 \\
\hline $\mathrm{K} 3-\mathrm{K} 4$ & - & - & - \\
\hline
\end{tabular}

$K 1-K 2=$ The experimental media treatment group;

K3 - K4 = The group without the media experiment treatment;

O1 = Observation of farmers' knowledge before being given extension media based on android X: Intervention (experimental treatment);

$\mathrm{O} 2$ = Observation of farmers' knowledge after being given extension media based on android.

2) The design of the model uses Partial Least Square (PLS) data with the Structural Equation Modeling (SEM) equation model. Model estimation was performed using the Smart PLS analysis tool. Data analysis activities consist of: (1) designing measurement models, (2) designing structural models and (3) building path diagrams, (4) converting path diagrams to equations, (5) estimating, (6) model fit test and (7) hypothesis testing.

Table 2 - Research stages

\begin{tabular}{|c|l|}
\hline Stages & Activities \\
\hline I Initial observations & Preliminary survey, analysis of problems and needs of lowland rice farmers' message about five farms \\
\hline $\begin{array}{c}\text { II Pure Experimental } \\
\text { Method }\end{array}$ & $\begin{array}{l}\text { Media design, media testing, validity and reliability testing of questionnaires, media testing, experimental treatment } \\
\text { (pretest and posttest) on the treatment group, data processing }\end{array}$ \\
\hline III Survey Methods & $\begin{array}{l}\text { Designing questionnaires, interviews, processing survey data to analyze models based on factors that affect the } \\
\text { media innovation function on the application of five farming, advanced combined data processing from stage II using } \\
\text { model analysis of the component and variant-based Structural Equation Model (SEM) equation }\end{array}$ \\
\hline
\end{tabular}




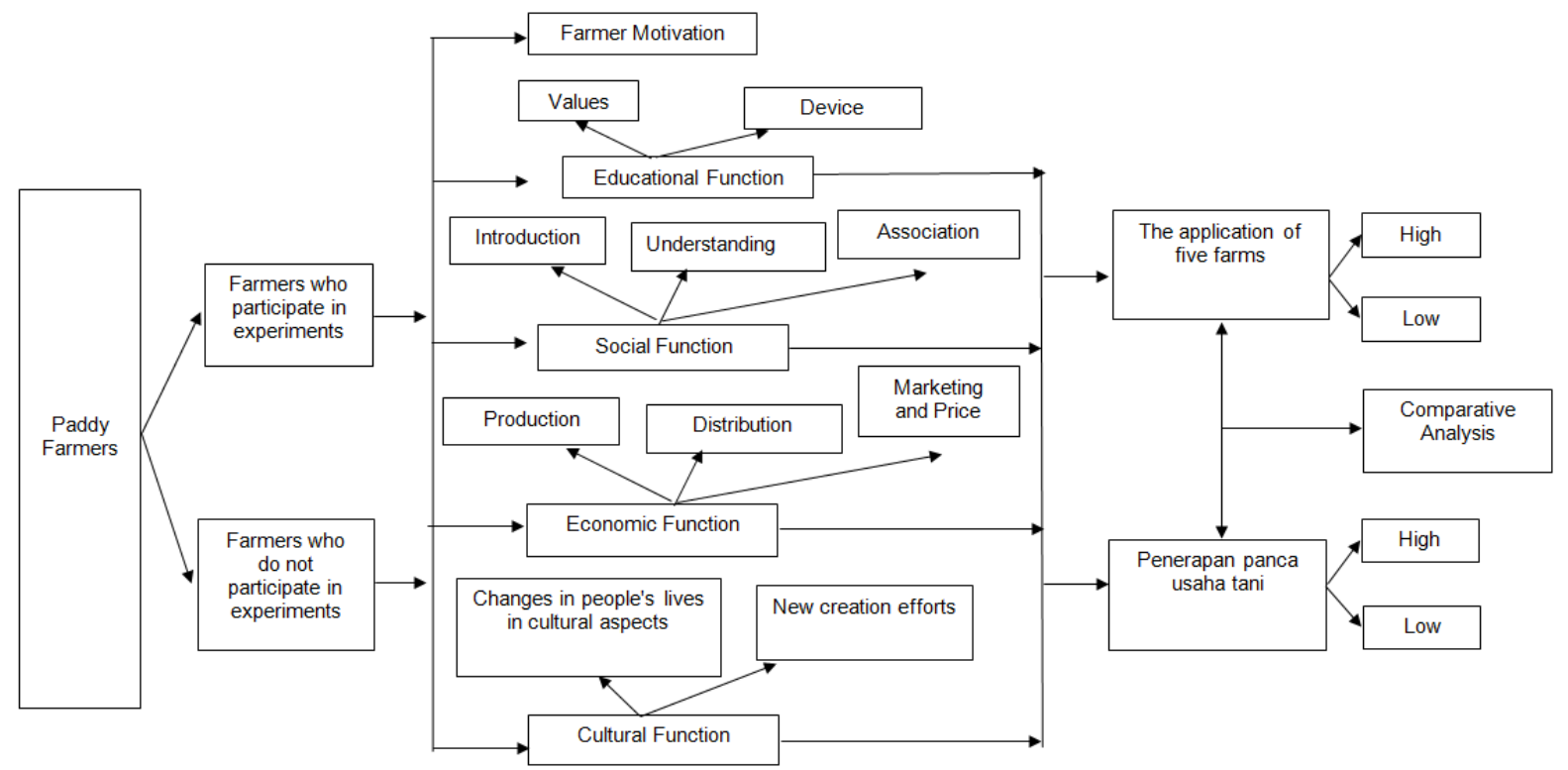

Figure 1 - Stages of research Android Based Media Innovation Function Model on the farming of Paddy toward Implementation of Five Farming system in The District of Tanjung Jabung Barat, Indonesia

\section{RESULTS AND DISCUSSION}

Differences in technology adoption among several farmers may occur due to differences in motivation. Motivation is an economic capital that moves people to be willing and willing to implement new innovations. The motivation of farmers towards adoption and innovation of new technology can be seen in Table 1.

Table 1 - Motivation of Farmers Implementation of Five Farming system in The District of Tanjung Jabung Barat, Indonesia

\begin{tabular}{|l|c|c|c|c|}
\hline \multirow{2}{*}{ Rice farming technology elements } & \multicolumn{2}{c|}{ PME } & \multicolumn{2}{c|}{ PNME } \\
\cline { 2 - 5 } & Score & $\%$ achieved & Score & $\%$ achieved \\
\hline Soil Processing & 45,5 & 75,6 & 43,4 & 73,4 \\
\hline Use of Varieties & 70,8 & 85,1 & 68,5 & 82,7 \\
\hline Nursery & 65,7 & 90,2 & 62,4 & 88,2 \\
\hline Planting & 80 & 82,5 & 78,7 & 80,8 \\
\hline Fertilization & 62,3 & 59,5 & 58,2 & 56,9 \\
\hline Weeding & 75,5 & 64,3 & 70,8 & 62,3 \\
\hline Pest and Disease Control & 55,6 & 65,2 & 52,4 & 61,5 \\
\hline Irrigation Arrangement & 72,4 & 70,8 & 64,3 & 65,6 \\
\hline Harvest and Post Harvest & 78,5 & 82,6 & 70,8 & 77,1 \\
\hline \multicolumn{1}{|c|}{ Total } & 67,37 & 75,09 & 63,28 & 72,06 \\
\hline
\end{tabular}

Note: $P M E=$ Farmers Participating in Experiments; $P N M E=$ Farmer Non Participating in Experiment .

Table 1 shows that the motivation of farmers towards implementing the elements of lowland rice innovation technology is categorized as quite high, medium and low. The motivation of farmers in applying technology to use superior varieties, nurseries, planting, harvesting and post-harvesting is quite high, while the important elements in rice farming are fertilization, pest and disease control, weeding, and irrigation arrangements. So in order to increase the adoption and innovation of rice farming technology, there must first be an effort to motivate farmers to the importance of technology to increase paddy farming productivity.

The educational function factor is the main function of every use of communication media, namely to educate because the use of communication media provides educational effects. Android-based extension media provide influence or good values to farmers. Education does not only take place in extension activities but can also use extension media, 
namely android-based media. The results of observations in the field show that most farmers are familiar with Andorid-based extension media and at least in each family there is one Android-based extension media. Even so, the activity of accessing agricultural information through internet media is still something new for farmers. Android-based extension media serves to educate farmers to think critically and can be a tool for farmers in making decisions and overcoming the limited number of extension agents. This is in accordance with the results of Damanik's research (2019) that the use of internet communication media is expected to overcome the shortage of agricultural extension workers in the city of Ambon. The educational function factor in implementing five lowland rice farming is in the high category as many as 45 people or $45 \%$. The high value presentation of the innovative function of using Android-based extension media is because the farmers in the research location really feel the benefits of using Android-based media as a medium to get information about agriculture, especially with regard to the five lowland rice farming. They feel that the existence of android-based media can provide added value in the form of increased knowledge and skills. Android-based media aids in the application of five paddy farming are mostly in the high category as many as 40 people or $66.67 \%$. The high percentage of android-based media as a tool is because most of the respondent farmers use androidbased media as a tool for them to get information in addition to the information they get from agricultural extension agents. This is in accordance with the results of research by Zulvera (2014) that the capacity of farmers needs to be increased by providing input to farmers and farmer groups through extension and institutional support using technology and informationbased media, opening information channels from all directions and strengthening extension support through competence and Continuous extension activities by considering policies that support the development of farming and the development of innovation from various parties, especially universities and research institutions.

The use of android-based extension media has an economic innovation function that is able to increase farmers' income, this is because the existence of android-based extension media can help farmers market their products to other areas. This is in line with the results of research conducted by Ahuja (2011) which found that the availability of agricultural information through the use of the internet helps farming communities to understand and sell agricultural products. The availability of technological information is a reference for farmers to understand the information provided through the media that is already available in the community (Ogbonna and Agwu 2013). This is because the information in the media is able to provide knowledge to farmers on how to increase lowland rice production by optimizing the use of production factors, namely the use of superior seeds, soil cultivation, irrigation, fertilization and pest control. The information they get is through youtube, the website and the WA group. Social Function Factors Android-based extension media not only provide authentic information and experiences in various fields of life but also provide the same concept to everyone. The direct effect of this is to expand the association, knowledge and understanding of people, customs, ways of getting along and everything about an area. This is very beneficial for the expansion of life and fostering a sense of unity and mutual respect among community members. Android-based extension media from the social aspect, namely as an introduction media, social media and understanding can increase farmers' knowledge in applying the five rice farming practices. This is because the use of Android-based extension media is able to combine elements of images, sound and text so that the information displayed becomes interesting. Cultural function factors Advances in information and communication technology (ICT) have an impact in the agricultural sector, namely the use of mobile phones as an Android-based extension media. Farmers in the research location have used Android-based extension media as an alternative media in finding information on five lowland rice farming in addition to information from agricultural extension agents. The reason they use Android-based extension media is because this media is able to provide information quickly, precisely, attractively, farmers can interact directly with other successful farmers. The use of Android-based extension media has changed the culture or habits of farmers from the habit of directly interacting with fellow farmers to interacting using Android-based extension media such as in buying and selling crops or to solve crop 
problems when attacked by pests, simply contact a pest expert with Android based media problem can be resolved.

The measurement model (outer model) shows how indicators (reflective) or manifest in presenting latent constructs are measured by testing the validity and reliability of latent constructs. The variable abbreviations used in the discussion of the research results are:

$\begin{aligned} \text { PME } & =\text { Farmers Participating in Experiments } \\ \text { PNME } & =\text { Farmer Non Participating in Experiment } \\ \text { MPBAE } & =\text { Android Based Extension Method } \\ \text { MPKNE } & =\text { Conventional Extension Methods } \\ \text { FIMPE } & =\text { Innovation Function Following Experimental Extension } \\ \text { FIMPNE } & =\text { Innovation Function Not Following Experimental Counseling } \\ \text { FEE } & =\text { Economic Functions of Experiment Participants } \\ \text { FBE } & =\text { Cultural Function of Experiment Participants } \\ \text { FedE } & =\text { Experiment Participant Education Function } \\ \text { FsosE } & =\text { Social Functions of Experiment Participants } \\ \text { FENE } & =\text { Non-Experimental Participant's Economic Function } \\ \text { FBNE } & =\text { Cultural Functions of Non-Experimental Participants } \\ \text { FedNE } & =\text { Non-Experimental Participant Education Function } \\ \text { FsosNE } & =\text { Social Functions of Non-Experimental Participants } \\ \text { PPUTE } & =\text { Application of Five Farming Experiments } \\ \text { PPUTNE } & =\text { Application of Five Farming Non Experiment } \\ \text { PT } & =\text { High Applicability } \\ \text { PR } & =\text { Low Applicability }\end{aligned}$

Table 2 - The Validity and Reliability Test Results of the Innovation Function Model of Android-Based Extension Media in Paddy Farming on the Implementation of Five Farming in the Research Area, 2020

\begin{tabular}{ccccc}
\hline & Cronbach Alfa & rho_A & Composite reliability & Mean variance in extracts (AVE) \\
\hline FIMPE & 0,337 & 0,445 & 0,541 & 0,371 \\
\hline FIMPNE & $-0,391$ & 0,016 & 0,199 & 0,260 \\
\hline PME & $-0,300$ & $-1,564$ & 0,474 & 0,497 \\
\hline PMNE & 0,626 & 0,721 & 0,835 & 0,719 \\
\hline PPUT & 0,449 & 2,840 & 0,684 & 0,566 \\
\hline
\end{tabular}

Source: Data processed by Smart PLS Version 3.0, 2020.

Convergent validity test through outer loading and AVE values by meeting values above 0.5 and 0.3 . The results of the algorithm calculation, all loading indicators for latent constructs are only conventional extension methods in the latent constructs of farmers following the experiment which have a value of $<0.5$, meaning that the conventional extension method has no relation to the experimental method based on android. Farmers who took part in the experiment tended to have a lot of knowledge about five farms before following the Android technology-based extension method. The average AVE value of the five research variables PME, PMNE, FIMPE, FIMPNE, and PPUT is above the value of 0.5 . This means that the absorption of five farms is strongly influenced by the motivation of the farmers and the productivity of rice farming. If farmer motivation and farmer productivity are high, the role of the innovation function of the android based extension model will affect the absorption of the five farms. The higher the outer loading value, it shows that this indicator is the most important in the latent variable / strongest measurement (Pirouz, 2006). Discriminant Validity The value of discriminant validity can be seen from the results of cross loading which show all variables of farmers following the experiment (PME), farmers not participating in the experiment (PNME), the innovation function of the experimental extension model (FIMPE), the innovation function of the non-experimental extension model (FIMPNE) and five absorption variables. Rice farming (PPUT) for each indicator can be said to be valid or good. The cross-loading variable of the android-based extension model on the absorption of five farms can be seen in Table 3.

Table 3 shows that the results of the PME cross loading value are negative, meaning that there are differences in technology adoption between the two groups of farmers. The cross loading value of FIMPE against FIMPNE is positive with a value of 0.662 . This means 
that the degree of influence of the two variables is $66.2 \%$. The amount of PME cross loading against FIMPNE is positive with a value of $0.20(20.0 \%)$. This means that participants who follow the experiment can affect FIMPNE by $20 \%$. The cross loading value of FIMPE to PPUT is negative with a value of 0.44 . This means that a $10 \%$ strengthening in FIMPE will result in a weakening of PPUT by $4.44 \%$. This can occur because the economic function with production, distribution, marketing and price instruments can be accessed properly by farmers. From the aspect of social functions, there is a more intensive introduction, association, and understanding of farmers. From the aspect of the educational function, increasing the value and tools available in the farmer's environment will reduce the willingness of farmers to adopt Android-based technology. From the aspect of cultural functions, there are changes in people's lives in terms of adopting new cultures and the absence of new creation efforts among farmers.

Table 3 - Cross Loading Variable Factors Model Functions of Extension Media Innovation based on Android-Based Paddy Farming Against Uptake of Five Farming in the Study Area

\begin{tabular}{llllll}
\hline & FIMPE & FIMPNE & PME & PMNE & PPUT \\
\hline FIMPE & 0,610 & & & & \\
\hline FIMPNE & 0,662 & 0,510 & & & \\
\hline PME & $-0,035$ & 0,200 & 0,705 & 0,848 & \\
\hline PMNE & $-0,121$ & 0,048 & 0,637 & 0,003 & 0,753 \\
\hline PPUT & $-0,444$ & $-0,547$ & $-0,137$ & 0 \\
\hline
\end{tabular}

Source: Data processed by Smart PLS Version 3.0, 2020.

The research reliability test aims to obtain a research instrument with high accuracy by looking at the composite reliability and Cronbach's alpha values. Latent constructs have good reliability if they have composite reliability and Cronbach's alpha is more than 0.5 (Hengky Latan, 2013). Table 15 shows that the five latent variables have composite reliability and cronbach's alpha values, namely the FIMPE factor of 0.337 and 0.371 , the FIMPNE factor of -0.391 and 0.260 . PME variable is -0.300 and 0.497 . PMNE variable with a value of 0.626 and 0.719. The PPUT variable has a value of 0.449 and 0.566 , meaning that on average the five variables are classified as realiable, there are several variables such as PMNE and PPUT latent variables in terms of rhO_A, the reliability of composite and AVE is very realiable.

Structural Model Fit Test (Inner Model) The inner model test is useful for seeing the relationship between latent variables (constructs) and other latent variables (constructs). Evaluation of the fit of the model (inner model) is through the R-squared (R2) test to measure the level of goodness of fit of a structural model and the path coefficient estimation test to determine how much influence the exogenous (independent) variable has on the endogenous (dependent) variable. The $R 2$ value in this study is seen in Table 4.

Table 4 - The R2 value of the Android-Based Extension Media Innovation Function Model in Paddy Farming on the Implementation of Five Farming system in the Research Area, 2020

\begin{tabular}{lll}
\hline & R Square & Adjusted R Square \\
\hline FIMPE & 0,018 & $-0,016$ \\
FIMPNE & 0,488 & 0,461 \\
PMNE & 0,406 & 0,396 \\
PPUT & 0,317 & 0,268 \\
\hline
\end{tabular}

Source: Data processed by Smart PLS Version 3.0, 2020.

Table 4 shows that the experimental extension model innovation function variable (FIMPE) has a R2 value of 0.0018 , meaning that the experimental extension model (FIMPE) innovation function variable can be explained jointly by economic factors (FE), cultural factors (FB). ), the educational variable (FED) and the social variable (FSOS) amounted to 1.8 percent. This precision value is classified as very low, this means that the innovation function of the experimental extension model is strongly influenced by other variables such as farmer 
motivation and rice farming productivity.

The direct effect is seen from the results of the path coefficient test which can be seen in Figure 4. The direct effect is the effect of the relationship between the independent variable (exogenous) on the independent variable (exogenous), the effect of the independent variable (exogenous) on the dependent variable (endogenous). The following results of the effect are presented in Table 5.

Table 5 - Path Analysis of the Relationship between Latent Variables of the Innovation Function Model of Android-Based Extension Media in Rice Farming on the Implementation of Five Farming System in the Research Area in 2020

\begin{tabular}{|c|c|c|c|c|c|c|}
\hline $\begin{array}{l}\text { Relations between } \\
\text { variables }\end{array}$ & $\begin{array}{l}\text { Path } \\
\text { Coefficient }\end{array}$ & $\begin{array}{l}\text { Rata-rata } \\
\text { sample }\end{array}$ & $\begin{array}{l}\text { Standard } \\
\text { Deviation }\end{array}$ & t-statistic & $P$ Value & Result \\
\hline PME -> FIMPE & 0,575 & 0,616 & 0,180 & 3,186 & 0,002 & $\begin{array}{l}\text { Positive and } \\
\text { significant }\end{array}$ \\
\hline PME -> PPUT & 0,277 & 0,245 & 0,184 & 1,505 & 0,134 & $\begin{array}{l}\text { Positive and not } \\
\text { Significant }\end{array}$ \\
\hline PMNE ->FIMPNE & 0,303 & 0,263 & 0,194 & 1,562 & 0,119 & $\begin{array}{l}\text { Positive and not } \\
\text { Significant }\end{array}$ \\
\hline PMNE -> PPUT & 0,497 & 0,461 & 0,231 & 2,149 & 0,032 & $\begin{array}{l}\text { Positive and } \\
\text { Significant }\end{array}$ \\
\hline FIMPE -> PPUT & 0,238 & 0,296 & 0,300 & 0,791 & 0,430 & $\begin{array}{l}\text { Positive and not } \\
\text { Significant }\end{array}$ \\
\hline FIMPNE -> PPUT & 0,825 & 0,825 & 0,055 & 14,932 & 0,000 & $\begin{array}{l}\text { Positive and } \\
\text { Significant }\end{array}$ \\
\hline
\end{tabular}

Source: Data processed by Smart PLS Version 3.0, 2020.

The conversion of path diagrams and PLS measurements into structural equations aims to express the causality relationship between various constructs whose values can be found in the PLS software from the PLS algorithm menu. The path diagram for indicators of internal and external factors that affect the sustainability of lowland rice farming in the Research Area through the PLS algorithm can be seen in Figure 4.

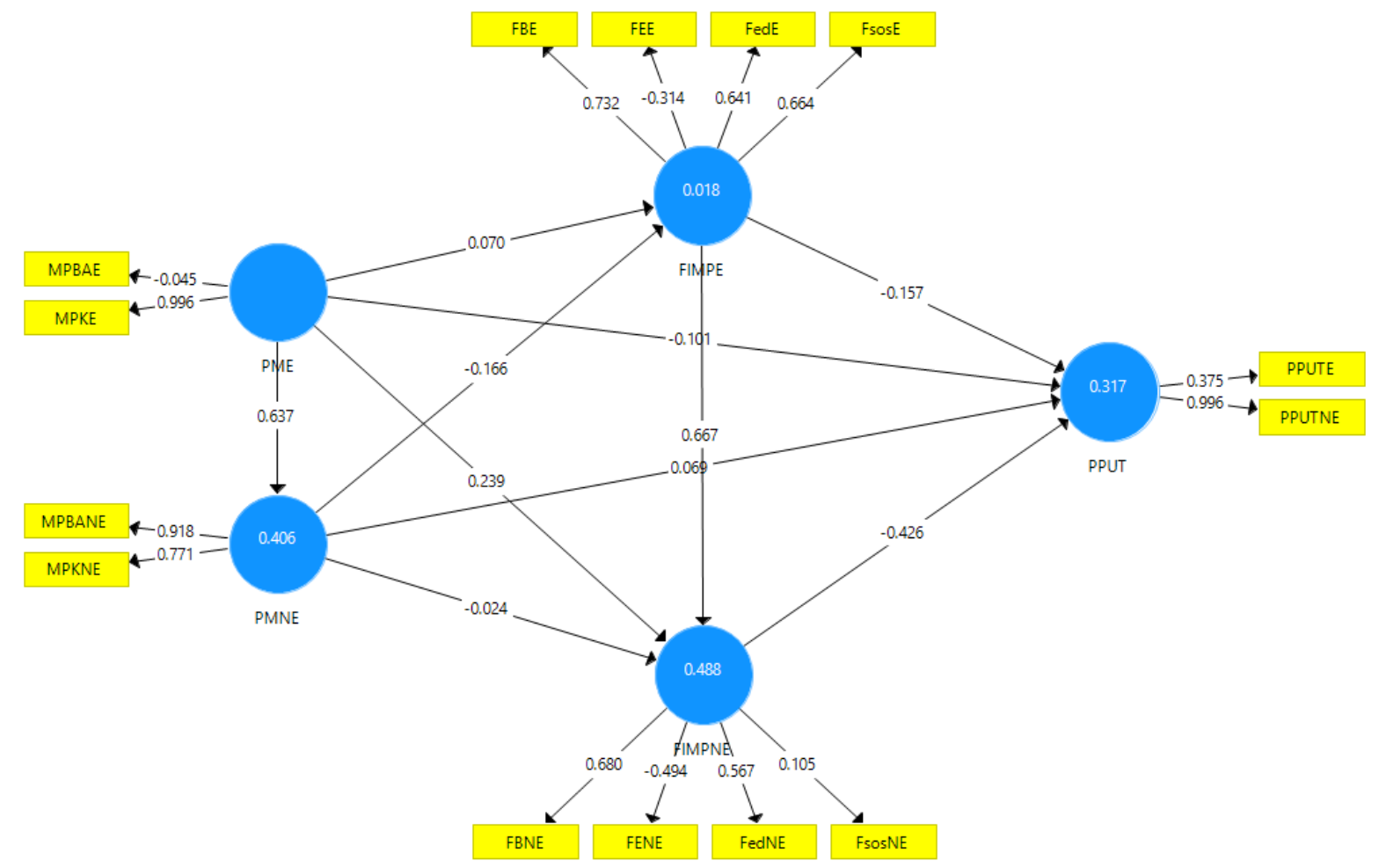

Figure 2 - The Path Diagram of the Variable Indicator for the Model of the Innovation Function of Android-Based Extension Media on the Implementation of Five Farming system in the Research Area in 2020 
Analysis of the Influence of Indicators on Latent Variables The latent variables in this study consisted of 5 variables, namely PME, PMNE, FIMPE, FIMPNE and PPUT variables. Each variable has several indicators that can explain these latent variables. The variable is said to be influential if the $t$ value $>t$ Table or seen from the P-value which is greater than the $\alpha=5 \%$, then the variable is said to have a significant effect.

\section{CONCLUSION}

Based on the results of research and discussion is: (1) The innovative design of android-based extension media uses a combination of text, video and images so that it looks attractive and the message content is easy for farmers to understand, (2) The factors that influence the innovation function of the extension services based on android consist of 4 manifest variables, namely education, economy, social and culture where the educational variables consist of values and tools, the economic variables consist of production, distribution and marketing / price, social variables. consists of introduction, association and understanding while cultural variables consist of change and creativity, (3) The value of cross loading shows that the value of loading of the constructs of sustainability of farming (economic, environmental and social aspects), namely $0.984,0.961$ and 0.960 , is higher than the cross loading indicators of other latent constructs, (4) The PNME variable (farmers who do not participate in the experiment) has a negative relationship with the FIMPNE variable of -0.024 , meaning that if there is a $10 \%$ strengthening of PMNE (Farmers Non-Participating in Experiments) it will weaken FIMPNE (Innovation Function Not Participating in Experimental Counseling) by $0.24 \%$ vice versa. The PMNE variable has a positive relationship with the PPUT variable of $0.069 \%$, meaning that if there is a $10 \%$ strengthening of PNME, it will strengthen PPUT by $0.69 \%$ and vice versa.

\section{REFERENCES}

1. BPS, 2018. Sub Sektor Pangan di Provinsi Jambi tahun (2018).

2. Damanik I and Tahitu, M.E. (2020). Perilaku Komunikasi Petani and Strategi penguatan Kapasitas Mengakses Informasi Pada Era Revolusi Industri 4.0 di Kota Ambon. FakultasPertanianUniversitasPattimura, Ambon. Jurnal Penyuluhan Vol. 16(01)2020|92104https://doi.org/10.25015/16202026365.

3. Departemen Pertanian (2002). Laporan Tahunan Departemen Pertanian Jakarta.

4. UU RI no 16 tentang sistem penyuluhan RI (2006). Sistem Penyuluhan and SP3 K di Indonesia.

5. Handayani SA, Efendi I, Viantimala B (2017). Produksi and pendapatan usahatani padi di desa Puji Asri Kec. Trimurjo Kab. Lampung tengah. JIIA, Vol 5, No 4.

6. Kementrian Pertanian (2017). Laporan Kinerja Direktorat Jenderal Tanaman Pangan 2016.

7. Kusumadinata, A.A. (2016). Penggunaan internet di Kalangan Petani Sayur dalam memperoleh informasi pertanian di Kabupaten Cianjur. Volume 7, Nomor 1. ISSN 2087 409X Indonesian Journal of Agricultural Economics (IJAE).

8. Safaat H., Nazruddin. (2011). Pemrograman Aplikasi Monile Smartphone and Tablet PC berbasis Android. Bandung: Informatika Bandung.

9. Sari MD and Surayya, M. (2018). Jenis media penyuluhan. BPTP Sumatera Selatan. Badan Litbang Pertanian, Kementrian Pertanian RI. http://sumsel.litbang.pertanian.go.id/

10. Madjid. A. (2006). Perencanaan Pembelajaran. Bandung. Remaja Rosdakarya.

11. Nadjib, A. H. (2016). Menumbuhkembangkan Inovasi di Daerah. Pengalaman Melaksanakan Laboratorium Inovasi Daerah di Kabupaten Muara Enim 2015. Badan Perencanaan Pembangunan Daerah (BAPPEDA) Kabupaten Muara Enim.

12. Notoadmojo. S. (2010). Metodologi Penelitian Ilmu Pertanian. Jakarta. Salemba Medika.

13. N. S. H. (2012). Pemrograman Aplikasi Mobile Smartphone and Tablet PC Berbasis Android, (Edisi Revisi) penyunting, Bandung: Informatika.

14. Saravanan, R. and Suchiradipta Bhattacharjee (2013). Mobile Phone and social media 
for Agricultural Extension: Getting to Hype and Hope. International Conference on Extension Educational Strategies for Sustainable Agricultural Development A Global Perspective. University of Agricultural Sciences, Bangalore, INDIA Dept. of Agricultural Extension, School of Social Sciences, College of Post Graduate Studies Central Agricultural University (CAU), Umiam (Barapani), Meghalaya.

15. Syaifullah (2014). Efektifitas media penyuluhan yang diberikan kepada petani karet di desa Gunung Bungsu Kecamatan III Kota Kampar. Jurnal Faperta Vol 2 No. 2.

16. Widodo, S and Nuraini, I (2014). Media Penyuluhan Pertanian. Universitas Terbuka. Edisi kedua. Jakarta.

17. You-Te Lu and Yi Hsing Chang (2016). Investigation of the internet adoption on senior farmers. Department of Information and Communication, Southern Taiwan University of Science and Technology, Tainan City, Taiwan.

18. Zakaria, S and Nagata, H. (2010). Knowledge creation and flow in agriculture: The experience and role of the Japanese extension advisors", Library Management, Vol. 31 No. 1/2, pp. 27-35. 